\title{
Sosyal Medya Reklamlarının Etkinliği, Empati Duygusu ve Satın Alma Niyeti Üzerine Ampirik Bir Araştırma ${ }^{1}$
}

\author{
Vural CAĞLIYAN \\ Prof. Dr. Selçuk Üniversitesi, \\ İktisadi ve İdari Bilimler Fakültesi, İşletme Bölümü, \\ vcagliyan@selcuk.edu.tr \\ Orcid ID: https://orcid.org/0000-0002-7964-8840

\section{Emel GELMEZ} \\ Dr. Öğr. Üyesi, Selçuk Üniversitesi, \\ İktisadi ve İdari Bilimler Fakültesi, İşletme Bölümü, \\ emelgelmez@selcuk.edu.tr \\ Orcid ID: https://orcid.org/0000-0002-8774-607X \\ Gizem GÜRAKAN \\ Selçuk Üniversitesi, Sosyal Bilimler Enstitüsü, \\ gizem.gurakan@hotmail.com \\ Orcid ID: https://orcid.org/0000-0002-5585-528X
}

\begin{abstract}
Öz
Gelişen teknolojiyle birlikte yeni iletişim ortamları ortaya çıkmaktadır. İnsanların düşüncelerini, bilgi ve deneyimlerini paylaştı̆̆ bir platform olan sosyal medya kullanımı gittikçe artan ve yaygın hale gelen yeni iletişim ortamlarındandır. Böyle bir ortamda sosyal medya reklamcılığ 1 , işletmelerin reklam etkinliklerini artırmaya yarayan bir araç olarak karşımıza çıkmaktadır. Sosyal medya reklamcılığı, tüketicilerin yeni ürünlerden haberdar olmasinda veya ilgi duyduğu ürünler hakkında detaylı bilgiye sahip olunmasında önemli rol oynamaktadır. Dolayısıyla sosyal medya reklamlarının içeriğini oluşturan sosyal medya reklam etkinliği, kişinin reklama karşı olumlu bir tutum sergilemesinde etkili bir unsurdur. Tüketicinin sosyal medya reklamlarına olumlu tutum sergilemesi ise satın alma niyetinin oluşmasını olumlu şekilde etkilemektedir. Çalışmada sosyal medya reklam etkinliği, olumlu bir davranış sergilemede yüksek etkiye sahip olan duygusal çekicilik, bilgi, yaratıcılık ve görsel tasarım

\footnotetext{
${ }^{1}$ Makale Geliş/Kabul Tarihi: 18.05.2020 / 29.06.2021

Künye Bilgisi: Çăglıyan, V., Gelmez, E. ve Gürakan, G. (2021). Sosyal medya reklamlarının etkinliği, empati duygusu ve satın alma niyeti üzerine ampirik bir araştırma. Kahramanmaraş Sütçü Imam Üniversitesi Sosyal Bilimler Dergisi, 18(2), 1116-1139. DOI: 10.33437/ksusbd.739292.
} 
kavramları çerçevesinde değerlendirilmiştir. $\mathrm{Bu}$ bağlamda sosyal medya reklamlarının etkinliği, empati ifadesine yönelik tutum ve satın alma niyeti arasındaki ilişki bir alan araştırması ile irdelenmiştir. Değişkenlerin birbirleri üzerindeki etkisini tespit edebilmek amacı ile yapısal eşitlik modelinden yararlanılmıştır. Analizler sonucunda sosyal medya reklamlarının etkinliği ile empati ifadesine yönelik tutum ve empati ifadesine yönelik tutum ile satın alma niyeti arasında istatistiksel bakımdan anlamlı bir ilişki tespit edilirken sosyal medya reklamlarının etkinliği ile satın alma niyeti arasında doğrudan bir ilişki tespit edilememiştir.

Anahtar Kelimeler: Sosyal Medya Reklamları, Empati İfadesine Yönelik Tutum, Satın Alma Niyeti, Yapısal Eşitlik Modeli.

\title{
An Empirical Investigation on the Effectiveness of Social Media Advertising, Empathy Expression and Intention of Purchasing
}

\begin{abstract}
With the developing technology, new communication environments emerge. The use of social media, a platform where people share their thoughts, knowledge and experiences, is one of the new communication environments that are becoming progressively widespread. In such an environment, social media advertising appears as a tool for increasing the advertising effectiveness of enterprises. Social media advertising plays an important role in informing consumers about new products or having detailed information about the products they are interested in. Therefore, the social media advertising effectiveness, which constitutes the content of social media ads, is an effective factor in a person's positive attitude towards advertising. The positive attitude of the consumer towards social media advertisements positively affects the formation of purchase intention. In this study, social media advertising effectiveness was evaluated within the framework of the concepts of emotional appeal, informativeness, creativity and visual design which have a high impact on positive behavior. In this context, the relationship between the effectiveness of social media advertisements, attitude towards empathy expression and purchase intention was examined by a field research. Structural equation modeling was performed in order to determine the effect of variables on each other. As a result of the analyzes, a statistically significant relationship was found between the effectiveness of social media ads and attitude towards empathy and attitude towards empathy expression and purchase intention, while no direct correlation was found between the effectiveness of social media ads and intention to purchase.
\end{abstract}


Keywords: Social Media Advertising, Attitude Toward Empathy Expression, Purchase Intention, Structural Equation Model.

\section{GİRIS}

Günümüzde teknoloji kullanımının artmasıyla birlikte sosyal medyanın da etkisi buna paralel olarak bir artış göstermektedir. Sosyal ağların giderek yaygınlaşması ile işletmelerin kullandığı reklam platformu, geleneksel medyadan ziyade sosyal medya ile şekillenmeye başlamaktadır. Tüketiciler sosyal medya sayesinde her an yeni bir üründen ya da markadan haberdar olmanın yanında, tercih ettiği ürün ya da marka hakkında da detaylı bilgi edinebilmektedir. Diğger yandan işletmeler de ürün ve hizmetleriyle ilgili pazarlama, satış ve geri bildirim gibi faaliyetlerini yine sosyal medya üzerinden daha hızlı ve etkili bir biçimde yapabilir duruma gelmişlerdir. $\mathrm{Bu}$ bağlamda sosyal medya reklamcıllğ 1 , işletmelerin reklam etkinliklerini artırmada ve tüketicilere ulaşma noktasında önemli bir araç olmaktadır. Aynı zamanda sosyal medya reklamcılığı, tüketicilerin yeni ürünlerden haberdar olması veya ilgi duyduğu ürünler hakkında detaylı bilgiye sahip olabilmesi açısından da önemli bir etkiye sahiptir.

Yukarıda yapılan açıklamalar çerçevesinde sosyal medya reklamlarının etkinliğinin ürüne karşı oluşan empati duygusu ve tüketicinin satın alma niyeti üzerine olan etkisi bu çalışmanın ana konusunu oluşturmaktadır. Bu bağlamda ilk olarak sosyal medya reklamlarının etkinliği, tüketicinin empati ifadesine yönelik tutumu ve satın alma niyeti kavramları açıklanacaktır. Sonrasında Konya ili Selçuk Üniversitesi öğrencilerinden toplanan veriler ile gerçekleştirilen ampirik bir araştırmanın bulguları paylaşılacaktır.

\section{LITERATÜR ÇALIŞMASI}

\section{Sosyal Medya Reklamlarının Etkinliği}

Teknoloji çağı olarak adlandırılan günümüzde insanların internet kullanım düzeyi ve sosyal medyanın etkisi her geçen gün artmaktadır. Sosyal medya, internet kullanıcılarının birbirleriyle çevrimiçi olarak iletişim kurmalarına imkân tanıyan, içerik paylaşımı ve bloglar oluşturarak kişisel yorumlar yapabilme gibi etkinliklere dayalı sosyal ağ siteleri olarak tanımlanabilmektedir (Kirtiş ve Karahan, 2011: 262). Düşük maliyetli olması, bilginin hızlı bir şekilde yayılması ve güncel olması, samimiyetin esas olduğu bir ortamda gerçekleşmesi, aracısız direkt olarak iletişim sağlayarak kişilerarası yakınlık sağlaması sosyal medyayı güçlü kılan unsurlardır (Eröz ve Doğdubay, 2012: 135).

Bilgi, deneyim, düşünce paylaşımı için sosyal medyayı aktif olarak kullanan tüketicilerin sayısının gün geçtikçe artmasıyla birlikte internet kullanımı pazarlama alanında önemli bir etken olarak ortaya çıkmaktadır (Tseng vd, 2014: 
29). Rekabetin artmasıyla işletmeler, tüketicilerin satın alma niyetlerini olumlu yönde etkilemek için tutundurma çabası içine girmektedirler. Bu yönü ile reklam, tüketicilerle iletişim kurmada en iyi ve etkili yol olmaktadır (Can ve Serhateri, 2016: 18). Reklam; ücretli, kişisel olmayan bir iletişim şekli olmakla birlikte ürünler hakkında tüketiciye bilgi ve fikir vererek markayı tanıtma amacı güden çabaların bütünüdür (Wei vd., 2010: 113). Bu doğrultuda işletmelerin tüketicilerle reklamlar yoluyla iletişim kurabilmesi için sosyal medya etkin bir ortam oluşturmaktadır.

Literatürde sosyal medya reklamlarının kullanıcılar tarafından ilgi görmesi ile ilgili reklamların eğlendiriciliği, güvenilir olması, bilgi-eğlence, kişiselleştirilmiş ürün içeriği, kişiselleştirilmiş fiyat içeriği, kişiselleştirilmiş promosyon içeriği, ekonomiye yararlılığı, değer yozlaşması, rahatsız etmesi, değer sağlaması, görsel tasarımı, duygusal çekiciliği, yaratıcılığı ve bilgilendiriciliği gibi farklı unsurlara rastlamak mümkündür (Logan vd., 2012; Hassan vd., 2013; Talih Akkaya, 2013; Dao vd., 2014; Gaber ve Wright, 2014; Turgut vd., 2016; Shaouf vd., 2016; Lee ve Hong, 2016). Bu bağlamda Lee ve Hong (2016) tarafindan gerçekleştirilen çalışmada sosyal medya reklamlarında kullanıcıların ilgisini çekmek adına nitelenen başlıca faktörlerin duygusal çekicilik, reklamların yaratıcilı̆̆l, reklamların bilgilendiriciliği (Lee ve Hong, 2016) olarak değerlendirildiği görülmektedir.

Ayrıca Shaouf vd. (2016) tarafindan yapılan bir başka çalışmada yukarıdaki unsurlara ilaveten reklamın görsel tasarımı isimli yeni bir boyuttan bahsedilmektedir. $\mathrm{Bu}$ çalışmada yazarlar görsel tasarım boyutunun reklama yönelik tutum ile arasında anlamlı ve pozitif yönlü bir ilişki olduğu ileri sürmüşlerdir. Buna ilaveten Can ve Serhateri (2016) tarafından yapılan bir başka çalışmada ise Shaouf vd. (2016) tarafından geliştirilen reklamların görsel tasarımı boyutu ile empati ifadesine yönelik tutum arasında ilişki olduğu ileri sürülmüştür. Bu bağlamda bu çalışmada sosyal medya reklamlarının etkinliğinin ölçülmesinde duygusal çekicilik, reklamların yaratıcıllğgl, reklamların bilgilendiriciliği (Lee ve Hong, 2016) ve reklamların görsel tasarımı (Shaouf vd., 2016) boyutlarından yararlanılmıştır. Bu dört boyut aşağıda açıklanmıştır.

Duygusal çekicilik, müşterinin ürüne karşı tutumunu etkileyerek reklamın gücünü artıran önemli bir unsurdur (Amjad vd., 2015: 467). Duygusallık, kişinin herhangi bir nesneye karşı beslediği hisler ile oluşmaktadır. Bahsedilen duygu, pozitif bir duygu (sevinç, mutluluk) olabildiği gibi, negatif bir duygu (korku, öfke, üzüntü) da olabilmektedir (Lee ve Hong, 2016: 364).

Duygu yüklü bir içeriğe sahip olan reklamın tüketiciler tarafından daha olumlu algılanmasıyla, reklamın değerini arttıracağı öngörülmektedir (Liu vd., 2012: 24). Bu doğrultuda sosyal ağlarda bir reklam içeriğindeki duygusal 
çekiciliğin tüketiciler arasında daha çok ilgi gördüğ̈̈ ve ağızdan ağıza pazarlamayla yayıldığı söylenebilmektedir (Swani vd., 2013: 271). Güçlü bir duygusal çekiciliğe sahip iletilerin çevrimiçi olarak paylaşılması olasılığı da daha yüksek olmaktadır (Alhabash vd., 2013: 176).

Reklamların yaratıcılığı, bir reklamın orijinalliğinin ve farklılığının ölçüsü şeklinde tanımlanmaktadır (Haberland ve Dacin, 1992: 818). Başka bir deyişle reklamın farklılığı ve ilgi düzeyi, reklam yaratıcılığının önde gelen özellikleri olarak görülmektedir. Farklılık, yeni ya da sıradışı olan unsurlarla ilişkilendirilirken; ilgi düzeyi tüketicilere anlamlı, uygun, yararlı ya da değerli olan unsurlarla ilişkilendirilmektedir (Smith vd., 2007: 820). Yaratıcı reklamlar tüketiciler tarafından daha fazla dikkat çekmekte ve öne çıkan ürünler hakkında tüketicilerin olumlu tutumlar sergilemelerine yol açmaktadır (Reinartz ve Saffert, 2013: 107-108). Yapılan çalışmalarda yaratıcı reklamların, tüketicilerin reklama karşı ilgisini artırdığı ve markaya değer kazandırdığı gözlemlenmiştir (Smith vd., 2007: 820-821). Bu bağlamda reklamların yaratıcılığının, bir reklamın etkinliği ile güçlü bir şekilde bağlantısı olduğu söylenebilir.

Reklamların bilgilendiriciliği, reklamların güncel olma ve zamanında, kolay erişilebilen bilgiler sunma yeteneği olarak değerlendirilmektedir. Tüketiciler bilgiye ihtiyaç duyduklarında bu bilgiye hızlı bir şekilde ulaşmayı ister. $\mathrm{Bu}$ bilginin tüketicilere sosyal medya reklamları yoluyla hızlı ve etkin bir şekilde iletilmesi mümkündür (Ling vd., 2010: 117). Yapılan çalışmalarda reklamların bilgilendirici olma özelliğinin, sosyal medya reklamlarına yönelik tüketici tutumlarının oluşturulması, müşteri tatminini ve satın alma niyetlerini etkileyen ve reklamın tüketici tarafından kabul edilmesi için önemli bir faktör olduğu görülmektedir (Ünal vd., 2011: 365; Taylor vd., 2011: 261-262). Bu bağlamda, bilgilendirici özelliği bulunan reklam içerikleri, tüketicilerin dikkatini çekerek zaman zaman bu iletileri sosyal ağ üzerinden arkadaşlarıyla paylaşmaya yönlendireceği değerlendirilmiştir.

Görsel tasarım, reklamların başarısının temel unsurlarından biri olarak kabul edilmektedir (Cho, 1999: 47). Reklamlarda etkili mesajlar kullanmanın tüketiciyi etkilemede önemli bir etken olduğu savunulmaktadır (Singh ve Dalal, 1999: 92). Görsel tasarım, tüketici davranışının öngörülmesinde en sık başvurulan ve güçlü teorilerden biri haline gelmektedir (Flores vd., 2014: 38-39). Sosyal medya reklamcılığındaki görsel tasarım; renk, şekil, resim, yazı tipi, yazı tipi boyutu vb. öğeleri içeren unsurlarla ilişskilidir (Dreze ve Zufryden, 1998: 82-84). Reklamlarda büyük boyutlu yazılar, canlı renkler ve animasyon gibi çeşitli dikkat çekici araçların kullanılması, tüketiciler üzerinde önemli bir etki bırakmaktadır. $\mathrm{Bu}$ tür araçlar müşterilerin tutumlarını olumlu yönde etkileyerek reklamın etkinliğini arttırmış olacaktır (Braun-Latour ve Zaltman, 2006: 57). 


\section{Empati İfadesine Yönelik Tutum}

Bir insanın, başkalarının duygularını kendi hisleri ve bakış açısıyla birleştirmesiyle empati kavramı ortaya çıkmaktadır. Psikologlar empatiyi, "kişinin, başkasının duygusal durumundan etkilenerek o duruma uyumlu bir duygusal tepki vermesi" olarak tanımlamaktadırlar (Escalas ve Stern, 2003: 567). Bu çalışmada empati, bir sosyal medya kullanıcısının sosyal medya reklamına karşı olumlu ya da olumsuz tepkilerini ifade ederek sosyal eklentileri kullanma yoluyla ağızdan ağıza pazarlama davranışında bulunması şeklinde değerlendirilmektedir (Lee ve Hong, 2016: 362-363). Bu bağlamda reklamc1lığa yönelik tutum da bir reklamın olumlu ya da olumsuz değerlendirilmesi şeklinde ifade edilebilmektedir. Empati ifadesine yönelik tutum da kavramsal olarak reklamcılığa dayanmaktadır. Ancak empati, kapsam olarak sosyal medya bağlamında (Lee ve Hong, 2016: 362-363) ele alınmaktadır.

Sosyal medya kullanımının artmasıyla birlikte sosyal medya reklamları da reklamcılığın etkinliğini artıran bir unsur olarak karşımıza çıkmaktadır. Sosyal medya kullanıcılarının tesadüfen karşılaştıkları reklamlara gösterdikleri olumlu tepkileri anlayabilmek oldukça zordur (Swani vd., 2013: 271). Sosyal medyada herhangi bir reklamı izleyen sosyal medya kullanıcıları, reklamı izlerken veya izledikten sonra duygusal bir etkide kalmaktadır. Reklama karşı oluşturdukları empatiyi, çevrimiçi bir sosyal ağ içerisinde sosyal eklentilerle ifade etmektedir (Lee ve Hong, 2016: 362). Öyle ki, sosyal medya kullanıcilarının empati davranışını gösteren empati ifadesinin bir örneği de 'beğen' düğmesidir (Swani vd., 2013: 271). Bir başka ifade ile hem içerik sağlayıcılarına hem de sosyal medya kullanıcılarına fayda sağlayan (Kontaxis vd., 2012: 631) sosyal eklentilerden beğen (like) düğmesi, empati ifadesinin bir örneğini oluşturmaktadır. Kullanıcılar, beğen'e tıklayarak kendi empatisini açık bir şekilde ortaya koyabilmektedir. Kullanıcılar beğen düğmesini tıkladığında, iletiyi gönderen kullanıcının duygusal durumunu anladıklarını ve duygularını paylaştıklarını göstermiş olmaktadırlar (Rosen, 2012). Dolayısıyla kullanıcılar etkisinde kaldıkları iletinin beğen düğmesine tıklayarak olumlu bir tutumda bulunmuş olmaktadırlar. Sosyal medya reklamlarına yönelik bir tutum sergileyen kullanıcıların olumlu bir satın alma niyetinde bulunduğu söylenebilmektedir (Lee ve Hong, 2016: 363).

Sosyal Medya Reklamları, Empati İfadesine Yönelik Tutum ve Satın Alma Niyeti

Literatürdeki sosyal medya reklam etkinliği, empati ifadesine yönelik tutum ve satın alma niyetini bir model olarak inceleyen bir çalışmaya rastlanılmamıştır. $\mathrm{Bu}$ bağlamda çalışma bu alandaki öncü bir çalışmadır. Bununla birlikte 
literatürde değişkenler arasındaki ilişkileri irdeleyen farklı çalışmalara rastlamak mümkündür.

Logan vd. (2012) tarafından ABD'deki üç büyük üniversitenin kız öğrencileri üzerinde yürütülen çalışmada sosyal medya reklam etkinliği olarak eğlence, bilgi ve rahatsız etme unsurları ele alınmış ve algılanan reklam değeri ile reklama yönelik tutumları değerlendirilmiştir. Sosyal medya reklam etkinliğinin eğlence ve bilgi faktörlerinin reklamın değeri üzerinde önemli bir etkisi olduğu görülürken, rahatsız etme faktörünün algılanan değerin değerlendirilmesinde önemli bir etkisinin olmadığ 1 fakat tüketici satın alma davranışında önemli bir etken olan reklama karşı tutumunu doğrudan etkilediği gözlemlenmiştir.

Haida ve Rahim (2015) çalışmasında Malezya'daki tüketicilerin sosyal medya reklamcılığına verdiği değeri eğlence, bilgilendiricilik ve rahatsız etme faktörleriyle ilişkilendirerek tüketicilerin algısını ölçmüş ve çalışma sonucunda rahatsız ederek dikkat çeken ve eğlendiren değil, bilgilendirici olan reklamların etkili olduğunu ileri sürmüştür.

Ünal vd. (2011) tarafından yapılan çalışmada ise Erzurum'da yaşayan genç ve yetişkin tüketicilerin mobil reklamlara yönelik tutumları incelenmiş ve güvenilirlik, eğlence ve bilgi faktörlerinin mobil reklama yönelik tutum üzerinde olumlu bir etkisinin olduğu sonucuna varılmıştır. Bunun yanında reklama yönelik tutum ile satın alma niyeti arasında da pozitif bir ilişki olduğu gözlemlenmiştir.

Lee ve Hong (2016) çalışmasında Kore'deki büyük bir üniversitenin öğrencilerine bir Facebook reklamı izletilmiş ve öğrencilerin reklama karşı gösterdiği empati ifadesi reklamın duygusal çekiciliği, bilgilendiriciliği ve yaratııılığ 1 kapsamında değerlendirilmiştir. Sosyal medya reklam etkinliği faktörlerinin empati ifadesine yönelik tutumu etkilediği ve bu tutumun satın alma niyetiyle de arasında pozitif bir ilişki olduğu gözlemlenmiştir.

Dao vd. (2014) yaptıkları çalışmada sosyal medya reklamcılığının bilgilendirici, eğlendirici ve güvenilirlik faktörlerinin tüketicilerin sosyal medya reklamlarına karşı algıladıkları değer üzerinde olumlu etkilerinin bulunduğunu ve bunun sonucunda da tüketicilerin çevrimiçi satın alma niyetlerini olumlu yönde etkilendiğini tespit etmişlerdir.

Ling vd. (2010) tarafından Malezya'da özel bir üniversitenin öğrencilerine uygulanan çalışma sonucunda ekonomi, güvenilirlik ve bilgi unsurları ile reklama karşı tutum arasında pozitif bir etkinin olduğu gözlemlenmiştir.

Liu vd. (2012) yaptıkları çalışmada farklı kültürler olarak Japon ve Avusturyalı tüketicilerin mobil reklamlara karşı algısını etkileyen unsurları bilgieğlence, rahatsız etme ve güvenilirlik olarak üç faktör şeklinde ele almış ve bu üç 
faktör ile algılanan reklam değeri arasında olumlu bir ilişki olduğu hem Japon hem de Avusturyalı tüketicilerde gözlemlenmiştir.

Wang vd. (2002), ABD'de büyük bir üniversitenin öğrencilerine ve personellerine uyguladığı çalışmada internet tabanlı reklamcılık ile geleneksel reklamcılık arasında algılanan farklılıkları eğlence, rahatsız etme, bilgi, güvenilirlik, etkileşim ve demografik faktörler kapsamında incelemiş ve reklama karşı tutum ile ilişkisini değerlendirmişlerdir.

Literatürde empati ifadesine yönelik tutum ile satın alma niyeti arasındaki ilişkiyi inceleyen çok az çalışma yer almaktadır. Lee ve Hong (2016) tarafindan yapılan çalışmada empati ifadesine yönelik tutumun satın alma niyetini geliştirerek olumlu yönde etkilediği görülmektedir. Yapılan literatür incelemesinden hareketle bir sosyal medya kullanıcısının olumlu empati davranışı göstermesi, reklamını izlediği ürün veya markaya karşı bir satın alma niyetinde bulunacağının göstergesi olduğu söylenebilmektedir. Bu bağlamda çalışma kapsamında yer alan değişkenler arasındaki ilişkilerin ve neden-sonuç etkilerinin belirlenmesine yönelik hipotezler geliştirilmiş olup araştırmanın metodolojisi kısmında detaylandırılarak incelenmiştir.

\section{METODOLOJI}

Çalışmanın bu bölümünde araştırmanın amacı, yöntemi ve örneklemi, modeli ve hipotezlerine yer verilmiştir.

\section{Araştırmanın Yöntemi ve Örneklem}

Araştırmanın temel amaci; sosyal medya reklamlarının etkinliğinin ürüne karşı oluşan empati duygusu ve müşterinin satın alma niyeti üzerine olan etkisinin incelenmesidir. Araştırmada veri toplama aracı olarak anket yöntemi kullanılmıştır. Araştırmanın örneklemi Selçuk Üniversitesi öğrencilerinden oluşmaktadır. Ana kütlenin tamamına ulaşmak daha fazla zaman ve yüksek maliyet gerektirmektedir. Bu sebeple çalışma, ana kütleyi temsil eden bir örneklem üzerinden yürütülmüş̧ür. Yazıcıŏglu ve Erdoğan (2014: 89) tarafından hazırlanmış olan belirli bir ana kütleyi temsil edecek olası örnek kütle rakamlarını gösteren tablo, ana kütleyi temsil edecek olan örnek kütlenin belirlenmesinde yol gösterici olmuştur. $\mathrm{Bu}$ bağlamda $73.308^{*}$ kişilik bir ana kütle için; $\pm 0,05$ örnekleme hatası; $p=0,05$ (ana kütledeki $X$ 'in gözlenme oran1) ve q=0,05 (ana kütledeki X'in gözlenmeme oranı) olmak kaydıyla belirlenen örnek kütle sayısı

*31.12.2018 tarihi itibarıyla Selçuk Üniversitesi’nde öğrenim gören öğrenci sayısıdır. Veriler, http://kalite.selcuk.edu.tr/KaliteDosyalar/DinamikMenu//SelcukUniversitesi2019tr.pdf sitesinden elde edilmiştir, Erişim Tarihi: 31.12.2018. 
383’tür. Veri toplama süreci olan Eylül-Aralık 2018 tarihlerinde değerlendirmeye uygun 400 anket elde edilmiştir. Bu bilgiler ışı̆̆ında örneklemin ana kütleyi temsil gücünün olduğu söylenebilir. Araştırmada örnekleme dahil edilecek katılımcıların belirlenmesinde kolayda örnekleme yöntemi kullanılmıştır. Kolayda örnekleme yöntemi, maliyeti düşük tutarak ucuz yoldan büyük bir örnek kütleye ulaşmaya imkan tanıması (Coşkun vd., 2017: 148) ve çok fazla sayıda veriye hızlı bir şekilde ulaşmayı sağlaması sebebiyle sıklıkla kullanılan bir yöntemdir (Nakip, 2013: 227).

Araştırmada kullanılan anket formu iki ayrı bölümden oluşmaktadır. Anketin birinci bölümünde katılımcıların özelliklerini belirlemeye ve katılımcıları tanımaya yönelik sorular bulunmaktadır. İkinci bölümde ise katılımcılar üzerinde sosyal medya reklamlarının etkinliğinin ve ürüne karşı oluşan empati duygusunun belirlenmesi ve müşterinin satın alma niyetinin tespit edilmesine yönelik ifadelere yer verilmiştir. Ölçekte yer alan maddeler 5'li Likert ölçeği ile derecelendirilmiş olup "1-kesinlikle katılmıyorum" ve "5-tamamen katıllyorum" anlamına gelmektedir.

Araştırma modelinin test edilmesinde Lee ve Hong (2016) çalışması esas alınmıştır. Lee ve Hong (2016) yaptığ 1 çalışmada reklama karşı oluşan empati duygusunu ölçmek amacıyla geliştirdiği dört maddeden oluşan tek boyutlu; sosyal medya reklamlarının etkinliğini ölçmek amacıyla geliştirdiği on maddeden oluşan üç boyutlu bir ölçekten yararlanmaktadır. Bu çalışmada sosyal medya reklamlarının etkinliğini ölçmek amacıyla dört boyutlu bir ölçek tasarlanmıştır. Lee ve Hong (2016) çalışmasındaki üç boyutlu sosyal medya reklamları etkinliğine dördüncü boyut olarak Shaouf vd. (2016) tarafından geliştirilen reklamların görsel tasarımı boyutu dahil edilerek bu çalışmada sosyal medya reklamlarının etkinliği dört boyut olarak ele alınmış olup yapısal geçerliliği test edilmiştir. Tüketicilerin satın alma niyetlerinin ölçülmesinde sosyal medya ile ilişkilendirilen bir ölçek olduğu için Shaouf vd. (2016) tarafından geliştirilen toplam üç maddeden oluşan tek boyutlu bir ölçekten yararlanılmıştır.

Ankette Lee ve Hong (2016) geliştirdiği duygusal çekicilik, reklamların yaratıcılığı ve reklamların bilgilendiriciliği boyutları, empati ifadesine yönelik tutum ölçeği ve Shaouf vd. (2016) tarafindan geliştirilen reklamların görsel tasarımı boyutu ve satın alma niyeti ölçeği Türkçeye çevrilmiştir. Yapılan çevirilerin geçerliliğini test amacıyla Türkçe ifadeler yeniden İngilizceye çevrilmiş ve orijinal metinle karşılaştırılarak hatalar düzeltilmiştir. 


\section{Araştırmanın Modeli ve Hipotezleri}

Araştırmanın amacına uygun olarak kavramsal bir model geliştirilmiş ve hipotezler bu model üzerinde belirtilmiştir. Araştırmanın kavramsal modeli Şekil 1'de gösterilmiştir.

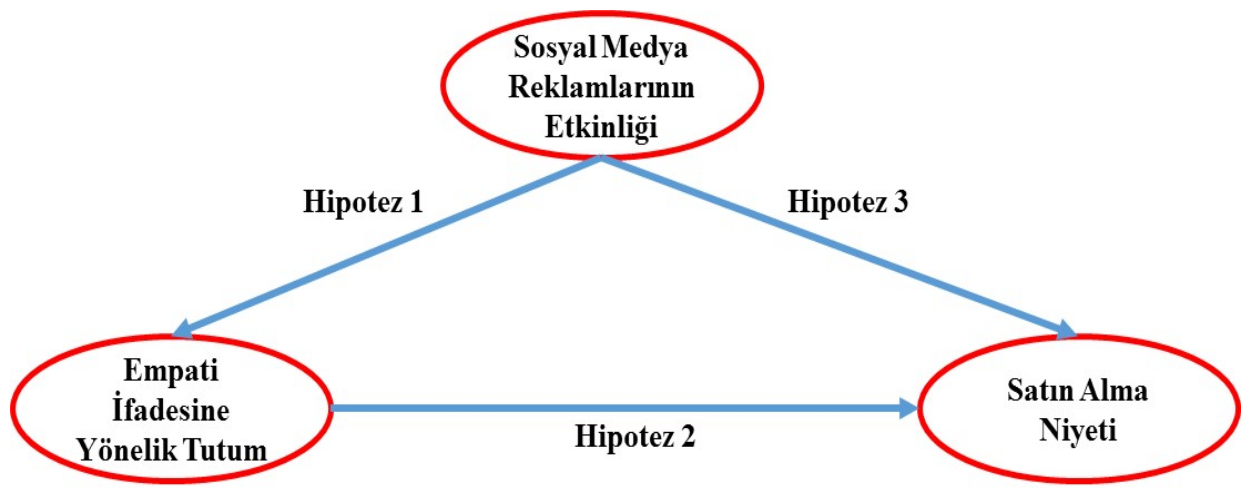

Şekil 1. Araştırmanın Kavramsal Modeli

Şekil 1'de şematize edilen araştırma hipotezleri aşağıdaki gibidir:

$\mathrm{H}_{1}$ : Sosyal medya reklamlarının etkinliği empati ifadesine yönelik tutumu pozitif yönde etkiler.

$\mathrm{H}_{2}$ : Empati ifadesine yönelik tutum satın alma niyetini pozitif yönde etkiler.

$\mathrm{H}_{3}$ : Sosyal medya reklamlarının etkinliği satın alma niyetini pozitif yönde etkiler.

\section{ARAŞTIRMANIN BULGULARI}

Çalışmanın bu kısmında araştırma örnekleminin özellikleri açıklanarak kurulan hipotezlerin doğruluğu test edilmiştir.

\section{Örneklemin Özellikleri}

Ankete katılan öğrencilerin demografik özelliklerini belirlemek amacı ile katılımcılara cinsiyet, yaş ve gelir seviyesi sorulmuştur. Geçerli 400 anket, istatistiksel analize tabi tutulmuştur. Örneklem incelendiğinde katılımcıların \%53,3'ününün kadın, \%46,8'inin erkeklerden oluştuğu tespit edilmiştir. Aynı zamanda katılımcıların büyük bir çoğunluğunun $(\% 59,8)$ 18-21 yaş grubu arasında olduğu görülmektedir. Öğrencilerinin gelir seviyelerinin \%35'nin 1000 TL'den az olduğu görülmekle birlikte \% 18,3'nün 4.001 ve üzerinde olduğu görülmüştür. 


\section{Verilerin Analizi}

Araştırmanın kavramsal modeli, Yapısal Eşitlik Modeli-YEM (Structural Equation Modeling)'den yararlanılarak test edilmiştir. Etkili bir model test etme yöntemi olarak YEM, değişkenler arasındaki neden-sonuç ilişkisini açılayabilmekte ve teorik modellerin bir bütün olarak test edilmesine imkân tanımaktadır. $\mathrm{Bu}$ bilgiler 1şı̆ıında YEM'in, araştırma yapılmadan önce değişkenler arasındaki ilişkileri gösteren araştırma modelinin, araştırma sonucunda elde edilen verilerle ne derece uyumlu olduğunu test eden bir yöntem olduğu söylenebilir (Ayyıldız vd., 2006). YEM analizi aşamasında SPSS-AMOS 18.0 programından faydalanılmıştır. YEM analizi yapılmadan önce ölçeklerin literatürde belirtilen boyutları taşıyıp taşımadığının test edilmesi amacıyla Keşifsel Faktör Analizi yapılmıştır. Analizin gerçekleştirilmesinde SPSS-22 istatistik paket programından faydalanılmıştır.

\section{Keşifsel Faktör Analizi}

Araştırma modelinin analizi için ilk olarak güvenirlilik analizi (reliability analysis) ve Keşifsel Faktör Analizi-KFA (Exploratory Factor Analysis) yapılmıştır. İkinci aşamada KFA ile tespit edilen boyutların doğrulanabilmesi için Doğrulayıcı Faktör Analizi-DFA (Confirmatory Factor Analysis) yapılmıştır.

Araştırmanın modelini yapısal analiz ile irdelemeden önce KFA ile modeldeki değişkenlerin tek boyutluluğu incelenmiş ve bu boyutların güvenilirliklerine bakılmıştır. Tablo 1'de ölçeklerdeki her bir boyuta ilişkin Cronbach Alpha ( $\boldsymbol{\alpha})$ değerleri ve her bir boyutun açıkladığ 1 Varyans (variance explaned/VE) parantez içinde gösterilmiştir. Ayrıca her bir boyutu ölçen maddelere ilişkin faktör yükleri ve diğer değerleri de belirtilmiştir. Tüm ölçekler için KFA'da faktör yüklerinin hesaplanmasında maksimum olabilirlik (maximum likelihood) tahmin yöntemi ve Varimax Döndürme Tekniği uygulanmış olup özdeğerleri 1'den büyük olan faktörler dikkate alınmıştır. Faktör yüklerinin ise 0,50 'den büyük olması şartı aranmıştır. KFA yapılmaya başlanmadan önce ölçeklerin güvenilirliğini artırmak için maddelerin toplam korelasyonları incelenmiş ve örnek büyüklüğünün faktör analizine uygunluğunu test etmek amaciyla Bartlett Sphericity Chi-Square Testi değerleri hesaplanmıştır. Hesaplanan değerler sonucunda KMO değerinin 0,60'dan büyük olması ve Chi-Square değerinin anlamlı çıkması beklenmiştir. Güvenirlilik analizlerinin sonucunda ise Cronbach Alpha değerlerinin 0,70'e eşit veya 0,70 ’ten büyük olması koşulu aranmıştır. 
Tablo 1. Keşifsel Faktör Analizi Sonuçları

\begin{tabular}{|c|c|c|c|c|c|c|}
\hline & Faktör/Boyut & Madde & $\begin{array}{c}\text { Faktör } \\
\text { Yükü }\end{array}$ & Ort. & $\begin{array}{l}\text { Std. } \\
\text { Sap. }\end{array}$ & $\begin{array}{c}\text { Boyu } \\
\text { t } \\
\text { Ort. }\end{array}$ \\
\hline \multirow{3}{*}{\multicolumn{2}{|c|}{$\begin{array}{l}\text { Reklamın } \\
\text { Duygusal } \\
\text { Çekiciliği } \\
(\boldsymbol{\alpha}=\mathbf{0 , 8 2 9} ; \\
\text { V.E=\%18,222; } \\
\text { Özdeğer=6,040) } \\
\end{array}$}} & $\begin{array}{l}\text { Sosyal medya reklamlarını izlemek } \\
\text { yoğun ilgi uyandırır. }\end{array}$ & 0,807 & 2,99 & 1,12 & \multirow{3}{*}{3,09} \\
\hline & & $\begin{array}{l}\text { Sosyal medya reklamlarının ana mesajı } \\
\text { beni duygusal olarak etkiler. }\end{array}$ & 0,809 & 3,08 & 1,00 & \\
\hline & & $\begin{array}{l}\text { Sosyal medya reklamlarının duygusal } \\
\text { yönü reklamı beğenmeme neden olur. }\end{array}$ & 0,718 & 3,20 & 1,01 & \\
\hline \multirow{11}{*}{ 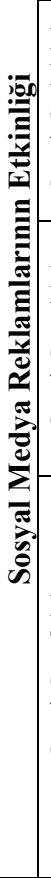 } & \multirow{3}{*}{$\begin{array}{l}\text { Reklamın } \\
\text { Bilgilendiriciliği } \\
(\boldsymbol{\alpha}=\mathbf{0 , 8 9 1 ;} \\
\text { V.E=\%17,822; } \\
\text { Özdeğer=1,456) }\end{array}$} & $\begin{array}{l}\text { Sosyal medya reklamlarından elde } \\
\text { edilen bilgiler kullanışlıdır. }\end{array}$ & 0,751 & 3,16 & 1,15 & \multirow{3}{*}{3,17} \\
\hline & & $\begin{array}{l}\text { Sosyal medya reklamlarını kullanmak } \\
\text { çok şey öğretir. }\end{array}$ & 0,838 & 3,19 & 1,10 & \\
\hline & & $\begin{array}{l}\text { Sosyal medya reklamlarından elde } \\
\text { edilen bilgiler yararlıdır. }\end{array}$ & 0,832 & 3,15 & 1,07 & \\
\hline & \multirow{4}{*}{$\begin{array}{l}\text { Reklamın } \\
\text { Yaratıc1lığ1 } \\
(\boldsymbol{\alpha}=\mathbf{0 , 7 4 0 ;} \\
\text { V.E=\%17,447; } \\
\text { Özdeğer=1,124) }\end{array}$} & Sosyal medya reklamları benzersizdir. & 0,600 & 3,26 & 1,02 & \multirow{4}{*}{3,31} \\
\hline & & $\begin{array}{l}\text { Sosyal medya reklamları gerçekten } \\
\text { sıra dışıdır. }\end{array}$ & 0,507 & 3,35 & 0,89 & \\
\hline & & $\begin{array}{l}\text { Sosyal medya reklamları merak } \\
\text { uyandırıcıdır. }\end{array}$ & 0,735 & 3,29 & 0,91 & \\
\hline & & Sosyal medya reklamları şaşırtıcıdır. & 0,739 & 3,34 & 0,97 & \\
\hline & \multirow{4}{*}{$\begin{array}{l} \\
\text { Reklamın Görsel } \\
\text { Tasarımı } \\
(\boldsymbol{\alpha}=\mathbf{0 , 7 8 7} ; \\
\text { V.E=\%15,263; } \\
\text { Özdeğer=1,005) }\end{array}$} & $\begin{array}{l}\text { Sosyal medya reklamlarının görsel } \\
\text { unsurlarının (renk,1şık, şekil vb.) } \\
\text { kalitesinin yüksek olması ilgimi çeker. }\end{array}$ & 0,753 & 3,34 & 1,05 & \multirow{4}{*}{3,41} \\
\hline & & $\begin{array}{l}\text { Sosyal medya reklamlarında kullanılan } \\
\text { görsel tasarımlar, reklama olan ilgimi } \\
\text { arttırır. }\end{array}$ & 0,743 & 3,42 & 0,92 & \\
\hline & & $\begin{array}{l}\text { Sosyal medya reklamlarının çekici } \\
\text { görsel bağlantılar içermesi ilgimi } \\
\text { çeker. }\end{array}$ & 0,734 & 3,41 & 1,03 & \\
\hline & & $\begin{array}{l}\text { Görsel olarak dikkatimi çeken } \\
\text { reklamlar genel olarak hoşuma gider. }\end{array}$ & 0,710 & 3,49 & 0,97 & \\
\hline \multicolumn{7}{|c|}{ N=400; KMO=0,892; Bartlett Sph. Testi, Chi-Square=2597,711, p<0,001; Faktör Yükleri $\geq 0,50$} \\
\hline \multirow{4}{*}{\multicolumn{2}{|c|}{$\begin{array}{l}\text { Empati İfadesine } \\
\text { Yönelik Tutum } \\
(\alpha=0,725 ; \\
\text { V.E=\%54,855; } \\
\text { Özdeğer=2,195) }\end{array}$}} & $\begin{array}{l}\text { Sosyal medya reklamlarında 'Beğeni' } \\
\text { butonuna tıklama konusunda kendimi } \\
\text { iyi hissederim. }\end{array}$ & 0,703 & 3,45 & 0,87 & \multirow{4}{*}{3,41} \\
\hline & & $\begin{array}{l}\text { Sosyal medya reklamlarında 'Beğeni' } \\
\text { butonuna tıklama konusunda kendimi } \\
\text { pozitif hissederim. }\end{array}$ & 0,780 & 3,46 & 0,88 & \\
\hline & & $\begin{array}{l}\text { Sosyal medya reklamları için "Beğeni" } \\
\text { butonuna tıklamayı olumlu buluyorum. }\end{array}$ & 0,737 & 3,35 & 0,87 & \\
\hline & & $\begin{array}{l}\text { Sosyal medya reklamlarına karşı genel } \\
\text { tutumum olumludur. }\end{array}$ & 0,741 & 3,38 & 0,81 & \\
\hline
\end{tabular}




\begin{tabular}{|l|l|c|c|c|c|}
\hline & $\begin{array}{l}\text { Sosyal medya reklamını gördükten } \\
\text { Sonra, reklamı yapılan ürünü satın } \\
\text { almaya yönelik ilgim artar. }\end{array}$ & 0,856 & 3,41 & 0,84 & \\
\cline { 2 - 5 } $\begin{array}{l}\text { Satın Alma Niyeti } \\
\mathbf{( \alpha = 0 , 8 1 2 ;}\end{array}$ \\
$\begin{array}{l}\text { V.E=\%72,670; } \\
\text { Özdeğer=2,180) }\end{array}$ & $\begin{array}{l}\text { Sosyal medya reklamını gördükten } \\
\text { sonra, reklamı yapılan ürünü satın } \\
\text { alma konusunda isteğim artar. }\end{array}$ & 0,877 & 3,31 & 0,82 & 3,31 \\
\cline { 2 - 5 } & $\begin{array}{l}\text { Sosyal medya reklamını gördükten } \\
\text { sonra, reklamı yapılan ürünü } \\
\text { muhtemelen satı alırım. }\end{array}$ & 0,823 & 3,22 & 0,82 & \\
\hline
\end{tabular}

N=400; KMO=0,705; Bartlett Sph. Testi, Chi-Square=408,416, $p<0,001$; Faktör Yükleri $\geq 0,50$

\section{Doğrulayıcı Faktör Analizi}

DFA, KFA'da belirlenen faktörlerin doğrulanması ve ölçeğin güvenilirliği ve geçerliliğinin test edilmesinin yanı sıra önerilen modelin istatistiksel açıdan anlamlılığını ve uyumluluğunu gösteren bazı değerler hesaplamaktadır. Değişkenlere ilişkin DFA sonuçları aşağıda Tablo 2'de verilmiştir.

Tablo 2. Ölçekler İçin Doğrulayıcı Faktör Analizi Sonuçları

\begin{tabular}{|c|c|c|c|c|c|}
\hline & Faktör/Boyut & Madde & $\begin{array}{l}\text { Standardiz } \\
\text { e } \\
\text { Regresyon } \\
\text { Ağırlığı }\end{array}$ & $T$ & $\boldsymbol{P}$ \\
\hline \multirow{11}{*}{ 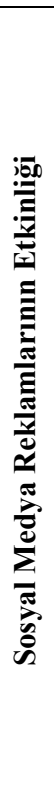 } & \multirow{3}{*}{$\begin{array}{c}\text { Reklamın Duygusal } \\
\text { Çekiciliği } \\
\left(\rho_{\eta}=0,88 ;\right. \\
\text { V.E }=0,72)\end{array}$} & $\begin{array}{l}\text { Sosyal medya reklamlarını izlemek } \\
\text { yoğun ilgi uyandırır. }\end{array}$ & 0,788 & 15,813 & $<0,001$ \\
\hline & & $\begin{array}{l}\text { Sosyal medya reklamlarının ana mesajı } \\
\text { beni duygusal olarak etkiler. }\end{array}$ & 0,758 & 14,316 & $<0,001$ \\
\hline & & $\begin{array}{l}\text { Sosyal medya reklamlarının duygusal } \\
\text { yönü reklamı beğenmeme neden olur. }\end{array}$ & 0,819 & - & \\
\hline & \multirow{3}{*}{$\begin{array}{c}\text { Reklamın } \\
\text { Bilgilendiriciliği } \\
\left(\rho_{\eta}=0,92 ;\right. \\
\text { V.E=0,795) }\end{array}$} & $\begin{array}{l}\text { Sosyal medya reklamlarından elde } \\
\text { edilen bilgiler kullanışlıdır. }\end{array}$ & 0,878 & 20,248 & $<0,001$ \\
\hline & & $\begin{array}{l}\text { Sosyal medya reklamlarını kullanmak } \\
\text { çok şey öğretir. }\end{array}$ & 0,867 & 22,326 & $<0,001$ \\
\hline & & $\begin{array}{l}\begin{array}{l}\text { Sosyal medya reklamlarından elde } \\
\text { edilen bilgiler yararlıdır. }\end{array} \\
\end{array}$ & 0,825 & - & \\
\hline & \multirow{4}{*}{$\begin{array}{c}\text { Reklamın Yaratıcılığ } 1 \\
\left(\rho_{\eta}=0,86\right. \\
\text { V.E }=0,61)\end{array}$} & Sosyal medya reklamları benzersizdir. & 0,610 & 10,533 & $<0,001$ \\
\hline & & $\begin{array}{l}\text { Sosyal medya reklamları gerçekten } \\
\text { sıra dişıdır. }\end{array}$ & 0,608 & 9,811 & $<0,001$ \\
\hline & & $\begin{array}{l}\text { Sosyal medya reklamları merak } \\
\text { uyandırıcıdır. }\end{array}$ & 0,651 & 9,689 & $<0,001$ \\
\hline & & Sosyal medya reklamları şaşırtıcıdır. & 0,704 & - & \\
\hline & $\begin{array}{l}\text { Reklamın Görsel } \\
\text { Tasarımı } \\
\qquad\left(\rho_{\eta}=0,882 ;\right.\end{array}$ & $\begin{array}{l}\text { Sosyal medya reklamlarının görsel } \\
\text { unsurlarının (renk,1şık, şekil vb.) } \\
\text { kalitesinin yüksek olması ilgimi çeker. }\end{array}$ & 0,684 & 12,040 & $<0,001$ \\
\hline
\end{tabular}




\begin{tabular}{|c|c|c|c|c|}
\hline V.E $=0,652)$ & $\begin{array}{l}\text { Sosyal medya reklamlarında kullanılan } \\
\text { görsel tasarımlar, reklama olan ilgimi } \\
\text { arttırır. }\end{array}$ & 0,697 & 10,464 & $<0,001$ \\
\hline & $\begin{array}{l}\text { Sosyal medya reklamlarının çekici } \\
\text { görsel bağlantılar içermesi ilgimi } \\
\text { çeker. }\end{array}$ & 0,634 & 11,623 & $<0,001$ \\
\hline & $\begin{array}{l}\text { Görsel olarak dikkatimi çeken } \\
\text { reklamlar genel olarak hoşuma gider. }\end{array}$ & 0,757 & - & \\
\hline & $\begin{array}{l}\text { Sosyal medya reklamlarında 'Beğeni' } \\
\text { butonuna tıklama konusunda kendimi } \\
\text { iyi hissederim. }\end{array}$ & 0,574 & - & \\
\hline $\begin{array}{l}\text { Empati İfadesine Yönelik } \\
\text { Tutum } \\
\quad\left(\rho_{\eta}=0,844 ;\right.\end{array}$ & $\begin{array}{l}\text { Sosyal medya reklamlarında 'Beğeni' } \\
\text { butonuna tıklama konusunda kendimi } \\
\text { pozitif hissederim. }\end{array}$ & 0,702 & 8,804 & $<0,001$ \\
\hline $\mathrm{V} . \mathrm{E}=0,576)$ & $\begin{array}{l}\text { Sosyal medya reklamları için "Beğeni" } \\
\text { butonuna tıklamayı olumlu buluyorum. }\end{array}$ & 0,620 & 8,187 & $<0,001$ \\
\hline & \begin{tabular}{|l|}
$\begin{array}{l}\text { Sosyal medya reklamlarına karşı genel } \\
\text { tutumum olumludur. }\end{array}$ \\
\end{tabular} & 0,630 & 8,138 & $<0,001$ \\
\hline & $\begin{array}{l}\text { Sosyal medya reklamını gördükten } \\
\text { sonra, reklamı yapılan ürünü satın } \\
\text { almaya yönelik ilgim artar. }\end{array}$ & 0,773 & - & \\
\hline $\begin{array}{r}\text { Satın Alma Niyeti } \\
\left(\rho_{\eta}=0,883 ;\right. \\
\text { V.E }=0,718)\end{array}$ & $\begin{array}{l}\text { Sosyal medya reklamını gördükten } \\
\text { sonra, reklamı yapılan ürünü satın } \\
\text { alma konusunda isteğim artar. }\end{array}$ & 0,838 & 13,261 & $<0,001$ \\
\hline & $\begin{array}{l}\text { Sosyal medya reklamını gördükten } \\
\text { sonra, reklamı yapılan ürünü } \\
\text { muhtemelen satın alırım. }\end{array}$ & 0,696 & 12,690 & $<0,001$ \\
\hline
\end{tabular}

Tüm ölçeklere ait maddelere ve bu maddelere ait standardize yüklere, $\mathrm{t}$ değerlerine ve $\mathrm{t}$ değerlerine karşılık gelen anlamlılık düzeylerine yukarıdaki tabloda yer verilmektedir. Ayrıca, her bir ölçeğin yapı güvenilirliği $\left(\rho_{\eta}\right)^{2}$ ve açılkadığı varyans $(\mathrm{VE})^{3}$ değerleri parantez içerisinde gösterilmiştir. Yapı güvenirliliği 0,70 'ten, açılanan varyans ise 0,50 'den büyük olmalıdır (Fornell ve Larcker, 1981: 45-46; Hair vd., 1998: 612). Bu doğrultuda tablo incelendiğinde her bir ölçeğin yapı güvenirlilik değerlerinin 0,70 'ten ve açıklanan varyanslarının da 0,50'den büyük olduğu görülmektedir. Ayrıca, her bir ölçeği temsil eden maddelerin standardize yüklerine karșıllk gelen $t$ değerleri ise istatistiksel açıdan anlamlıdır. $\mathrm{Bu}$ bilgiler doğrultusunda keşifsel faktör analizinde tespit edilen durumun, her üç ölçek için de doğrulayıcı faktör analizinde tespit edildiği görülmektedir.

${ }^{2} \boldsymbol{\rho}_{\eta}$ : Yapı Güvenirliliği $=\left(\sum \text { standardize reg.ağr. }\right)^{2} /\left(\sum \text { standardize reg.ağr. }\right)^{2}+\sum$ ölçüm hatalar

${ }^{3}$ VE: Açıklanan Varyans $=\sum\left(\right.$ standardize reg.ağr. $\left.{ }^{2}\right) / \sum\left(\right.$ standardize reg.ağr. $\left.{ }^{2}\right)+\sum$ ölçüm hataları formülleri yardımıyla hesaplanmıştır. 


\section{Yapısal Eşitlik Analizi Sonuçları}

Araştırmanın modelini oluşturan temel değişkenlerin doğrulanmasından sonra hipotezlerin test edilmesinde yapısal eşitlik analizinden yararlanılmıştır. Araştırmanın modelinde bulunan değişkenler arasındaki ilişkiler incelenmeden önce bu modelin istatistiksel açıdan anlamlı ve geçerli olup olmadığının tespit edilmesi gerekmektedir. Doğrulayıcı faktör analizinde ve YEM'de elde edilen sonuçların istatistiksel açıdan anlamlı ve geçerli olup olmadığının tespit edilmesinde uyum iyiliği değerlerinden yararlanılmaktadır.

Kullanılan paket programa göre YEM'de uyum iyiliği değerleri değişiklik gösterebilmektedir. YEM sınamasında kullanılan farklı istatistik programlarında farklı sayıda ve türde uyum istatistiği verilmektedir. Örneğin LISREL, modelin veriye uyumunun farklı yönlerini değişik ölçütlere göre değerlendiren 15 farklı uyum istatistiği vermektedir (Şahin vd., 2008). Bu doğrultuda AMOS programı sonucunda elde edilen ve araştırmanın kapsamında değerlendirilen indeksler ve bu indekslere ait değerlendirme ölçütleri ile yapısal modele ait uyumluluk ölçüleri aşağıda Tablo 3’te verilmiştir.

Tablo 3. Yapısal Modele İlişkin Uyum Ölçüleri

\begin{tabular}{|l|l|l|l|}
\hline $\begin{array}{l}\text { Uyum } \\
\text { Ölçüleri }\end{array}$ & İyi Uyum & $\begin{array}{l}\text { Kabul Edilebilir } \\
\text { Uyum }\end{array}$ & $\begin{array}{l}\text { Önerilen } \\
\text { Model }\end{array}$ \\
\hline GFI & $0,95 \leq \mathrm{GFI} \leq 1$ & $0,90 \leq \mathrm{GFI} \leq 0,95$ & 0,969 \\
\hline AGFI & $0,90 \leq \mathrm{AGFI} \leq 1$ & $0,85 \leq \mathrm{AGFI} \leq 0,9$ & 0,950 \\
\hline RFI & $0,90 \leq \mathrm{RFI} \leq 1$ & $0,85 \leq \mathrm{RFI} \leq 0.90$ & 0,942 \\
\hline RMSEA & $0<\mathrm{REMSEA}<0,05$ & $0,05 \leq \mathrm{RMSEA} \leq 0,10$ & 0,047 \\
\hline$\chi^{2} / \mathrm{df}$ & $0<\chi^{2} / \mathrm{df}<3-5$ & $76,477 / 41=1,865$ \\
\hline
\end{tabular}

Not: GFI (Goodness of Fit Index/Uyum İyiliği İndeksi), AGFI (Adjusted Goodness of Fit Index/Düzeltilmiş İyilik Uyum İndeksi), RFI (Relative Fit Index/Göreli Uyum İndeksi), RMSEA (Root Mean Square Error of Approximation/Yaklaşım Hatasının Kök Ortalama Karesi).

Model ile veri arasındaki uyumun test edilmesinde $\chi^{2} /$ serbestlik derecesi değeri kullanılabilir. Ki Kare (Chi Square) değeri $0<\chi^{2} / \mathrm{df}<3-5$ derecesinde yani oranın sıfıra yakın ya da en az 5'in altında olmalıdır (Yeniçeri ve Erten, 2008). Çalışmada modelin oranı $76,477 / 41=1,865$ 'dir. Serbestlik derecesinin büyük olması $\chi^{2}$ değeri anlamlı sonuçlar verme eğiliminde olduğunu gösterir. $\mathrm{Bu}$ sebeple serbestlik derecesi $\chi^{2}$ değeri çok önemli bir ölçüt olmakla beraber 3 ve daha yüksek olan oranlar iyi uyum, 5'e kadar olan oranlar ise yeterli uyum olarak kabul edilmektedir (Marsh ve Hocevar, 1988). Bu bağlamda modele ilişkin $\chi^{2}$ değerinin iyi uyum gösterdiği söylenebilir. 
GFI; önerilen modelde hesaplanan gözlenen değişkenler arasındaki genel kovaryans miktarını gösteren bir değerdir. Uyum iyiliği indeksinde 0,95 ile 1,00 aralığındaki değer iyi bir uyumun varlığını, 0,90 ile 0,95 aralığındaki değer ise kabul edilebilir bir uyumun varlığını gösterir (Eminoğlu ve Nartgün, 2009).

AGFI; örneklem genişliğine dikkat edilerek düzeltilmiş olan bir GFI değeridir. AGFI, özellikle örneklem genişliği büyük olduğunda temsil yeteneği daha güçlü bir uyum indeksi olarak kabul edilir. AGFI, serbestlik derecesi ve GFI değerleri biliniyorsa basit bir şekilde hesaplanabilir. AGFI 0 ile 1 arasında değer alır. Değer 1'e yaklaştıkça modelin uyumu artar (Tezcan, 2008). Model veri uyumu için GFI ve AGFI değerlerinin 0,90'dan yüksek, RMSEA değerinin ise 0,05 'den küçük olması beklenir. Buna karşılık GFI değerinin 0,85 'ten, AGFI* değerinin 0,80 'den yüksek ve RMS değerinin ise 0,10 'dan düşük çıkması modelin gerçek verilerle uyumu için birer ölçüt olarak da kabul edilebileceğini gösteren sonuçlardır (Anderson ve Gerbing, 1984; Cole, 1987; Marsh vd., 1988'den aktaran Gülbahar ve Büyüköztürk, 2008). Bu bağlamda araştırma modeline ilişkin GFI değeri 0,969 ve AGFI değeri de 0,950'dir. Bu sonuçlara göre değerler iyi uyum sınırları içerisindedir.

Veri ile model arasındaki uyumu değerlendirmek için kullanılan bir diğer ölçüt RFI uyum kriteridir. RFI de 0-1 arasında değer alır. Değerin 0,85 ve 0,90 arasında bir değer alması beklenir (Çakır ve Çakır, 2007). Modele ilişkin RFI değeri 0,942 olup iyi uyum gösteren bir değerdir.

RMSEA ise örneklemde gözlenen değişkenler arasındaki kovaryansla modelde önerilen parametreler arasındaki farkın yani hatanın derecesi temelinde geliştirilmiş olan mutlak uyum indeksidir. GFI ve AGFI'nin aksine " 0 " a yakın değer vermesi beklenir. 0,05 ' e eşit veya daha küçük olan değer mükemmel, 0,08 ve altındaki değer de model karmaşıklığı dikkate alınarak kabul edilen değer olarak görülebilmektedir (Haşlaman, 2005). Modele ilişkin RMSEA değeri 0,047'dür. Bu değer model karmaşıklığı dikkate alındığında mükemmel uyumlu bir değer olarak değerlendirilmiştir.

Yukarıdaki Tablo 3 dikkate alındığında yapısal modele ait uyum ölçütü (RMSEA, GFI, AGFI, RFI ve $\chi^{2}$ ) değerlerine ilişkin sonuçlar, geliştirilen kavramsal modelin veri ile uyumlu olduğu ve modelin istatistiksel açıdan geçerli ve anlamlı olduğunu göstermektedir. Bu doğrultuda araştırmanın modelinde iddia edilen hipotezlerin değerlendirilmesi için modelin istatistiksel olarak geçerli bir model olması zorunluluğu sağlanmıştır. 


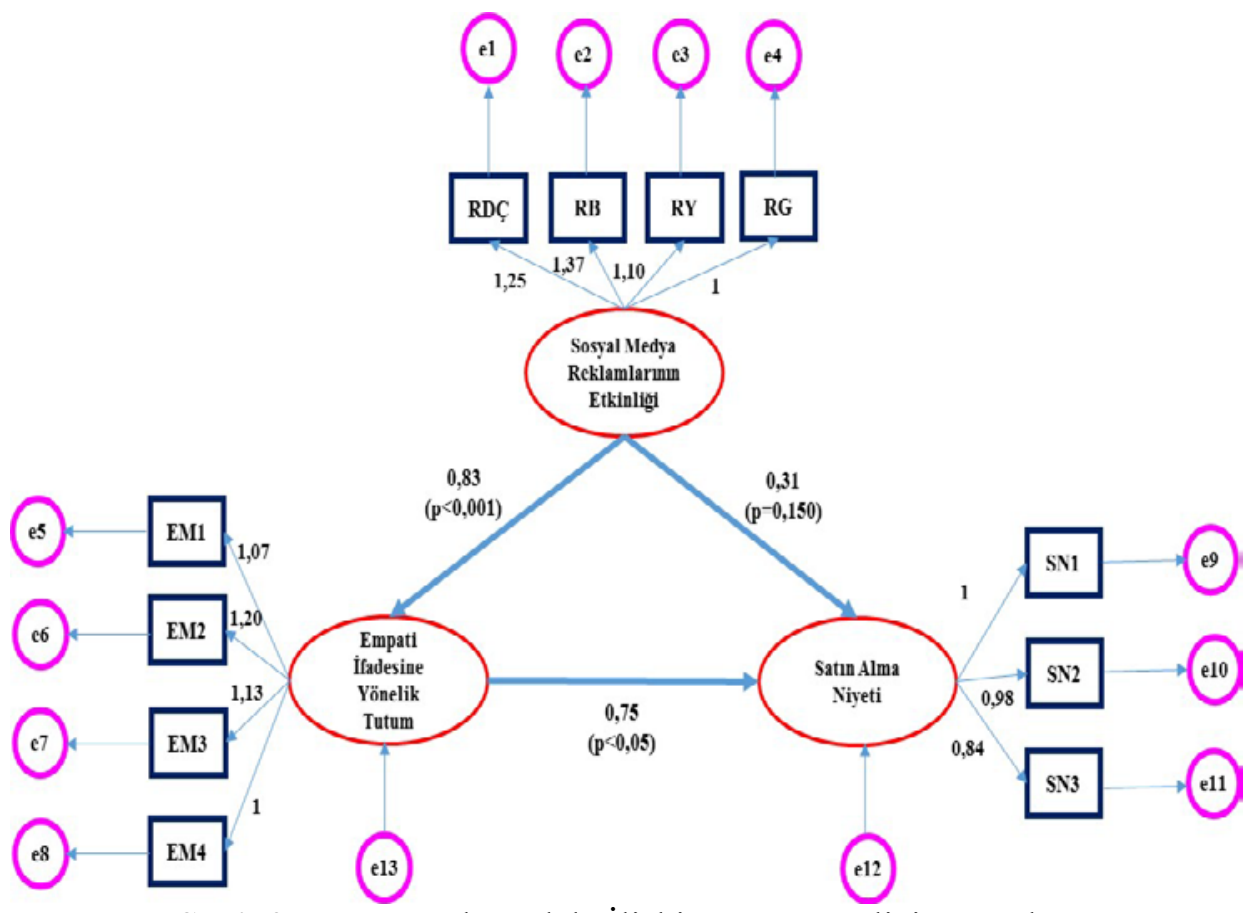

Şekil 2. Kavramsal Modele İlişskin YEM Analizi Sonuçları

Şekil 2'deki modele ilişkin bilgiler Tablo 4 ve 5'teki gibi özetlenebilir.

Tablo 4. Kavramsal Modele İlişkin YEM Analizi Sonuçları

\begin{tabular}{|c|c|c|c|c|}
\hline Faktör & Boyut/Madde & $\begin{array}{c}\text { Std. } \\
\text { Tahmin }\end{array}$ & $\begin{array}{l}\text { Standart } \\
\text { Hata }\end{array}$ & $t^{*}$ \\
\hline \multirow{4}{*}{$\begin{array}{l}\text { Sosyal } \\
\text { Medya } \\
\text { Reklamla } \\
\text { rının } \\
\text { Etkinliği }\end{array}$} & Reklamın Duygusal Çekiciliği & 1,247 & ,105 & 11,918 \\
\hline & Reklamın Bilgilendiriciliği & 1,368 &, 114 & 11,946 \\
\hline & Reklamın Yaratıcılığ & 1,102 & 084 & 13,114 \\
\hline & Reklamın Görselliği & 1,00 & - & - \\
\hline \multirow{4}{*}{$\begin{array}{l}\text { Empati } \\
\text { İfadesine } \\
\text { Yönelik } \\
\text { Tutum }\end{array}$} & $\begin{array}{l}\text { Sosyal medya reklamlarında 'Beğeni' } \\
\text { butonuna tıklama konusunda kendimi } \\
\text { iyi hissederim. }\end{array}$ & 1,073 & 113 & 9,509 \\
\hline & $\begin{array}{l}\text { Sosyal medya reklamlarında 'Beğeni' } \\
\text { butonuna tıklama konusunda kendimi } \\
\text { pozitif hissederim. }\end{array}$ & 1,201 & 114 & 10,492 \\
\hline & $\begin{array}{l}\text { Sosyal medya reklamları için "Beğeni" } \\
\text { butonuna tıklamayı olumlu buluyorum. }\end{array}$ & 1,130 & 112 & 10,058 \\
\hline & $\begin{array}{l}\text { Sosyal medya reklamlarına karşı genel } \\
\text { tutumum olumludur. }\end{array}$ & 1,00 & - & - \\
\hline
\end{tabular}




\begin{tabular}{|c|c|c|c|c|}
\hline \multirow{3}{*}{$\begin{array}{l}\text { Satın } \\
\text { Alma } \\
\text { Niyeti }\end{array}$} & $\begin{array}{l}\text { Sosyal medya reklamını gördükten } \\
\text { sonra, reklamı yapılan ürünü satın } \\
\text { almaya yönelik ilgim artar. }\end{array}$ & 1,00 & - & - \\
\hline & $\begin{array}{l}\text { Sosyal medya reklamını gördükten } \\
\text { sonra, reklamı yapılan ürünü satın alma } \\
\text { konusunda isteğim artar. }\end{array}$ & 976, & ,063 & 15,469 \\
\hline & $\begin{array}{l}\text { Sosyal medya reklamını gördükten } \\
\text { sonra, reklamı yapılan ürünü } \\
\text { muhtemelen satın alırım. }\end{array}$ & 844 & ,063 & 13,365 \\
\hline
\end{tabular}

* Bütün $t$ değerleri için $p<0,001$.

Tablo 5. Hipotez Test Sonuçları

\begin{tabular}{|l|c|c|c|c|c|}
\hline Hipotez & $\begin{array}{c}\text { Std. } \\
\text { Tahmin }\end{array}$ & Std. Hata & T & p & Sonuç \\
\hline $\begin{array}{l}\text { Sosyal medya } \\
\text { reklamlarının etkinliği } \\
\text { empati ifadesine yönelik } \\
\text { tüumu pozitif yönde } \\
\text { etkiler. }\end{array}$ & 0,829 & 0,084 & 9,868 & $<0,001$ & Kabul \\
\hline $\begin{array}{l}\text { Empati ifadesine yönelik } \\
\text { tutum satın alma niyetini } \\
\text { pozitif yönde etkiler. }\end{array}$ & 0,746 & 0,241 & 3,090 & $<0,05$ & Kabul \\
\hline $\begin{array}{l}\text { Sosyal medya } \\
\text { reklamlarının etkinliği } \\
\text { satın alma niyetini pozitif } \\
\text { yönde etkiler. }\end{array}$ & 0,309 & 0,215 & 1,440 & 0,150 & Red \\
\hline
\end{tabular}

Şekil 2, Tablo 4 ve 5 birlikte değerlendirildiğinde sosyal medya reklamlarının etkinliği değişkeni ile empati ifadesine yönelik tutum arasındaki ilişki katsayısı 0,83 ve $\mathrm{p}<0,001$ 'dir. Bu sonuçlara göre $\mathrm{H}_{1}$ : "Sosyal medya reklamlarının etkinliği empati ifadesine yönelik tutumu pozitif yönde etkiler." hipotezi kabul edilmiştir. Bu bağlamda elde edilen sonucun literatürle benzerlik gösterdiği görülmektedir (Lee ve Hong, 2016; Can ve Serhateri, 2016; Talih Akkaya, 2013; Logan, 2012).

Empati ifadesine yönelik tutum değişkeni ile satın alma niyeti arasındaki ilişki katsayıs1 0,75 ve $\mathrm{p}<0,05$ 'tir. Bu sonuçlara göre $\mathrm{H}_{2}$ : "Empati ifadesine yönelik tutum satın alma niyetini pozitif yönde etkiler." hipotezi kabul edilmiştir. Lee ve Hong (2016) tarafindan yapılan çalışmada, empati ifadesine yönelik tutumun bir empati ifade etme niyeti göstererek satın alma niyetini etkilediği tespit edilmiştir. Dolayısıyla bu çalışmada elde edilen sonucun literatürle benzerlik gösterdiği söylenebilir. 
Sosyal medya reklamlarının etkinliği değişkeni ile satın alma niyeti arasındaki ilişki katsayısı 0,31 ve $\mathrm{p}=0,150$ 'dir. Bu sonuçlara göre $\mathrm{H}_{3}$ :"Sosyal medya reklamlarının etkinliği satın alma niyetini pozitif yönde etkiler.” hipotezi reddedilmiştir. Literatür incelendiğinde reklam etkinliği unsurlarından reklam yaratııılığının satın alma niyeti ile arasında bir ilişki olduğu (Saputro ve Prihandono, 2018); Turgut vd., (2016) tarafından yapılan çalışmada ise reklamların eğlence ve bilgi faktörlerinin satın alma niyetiyle arasında bir ilişki bulunmadığı sonucuna ulaşılmıştır.

\section{SONUÇ}

Çalışmanın temel amacı, sosyal medya reklamlarının etkinliğinin reklama karşı oluşan empati duygusu ve tüketicinin satın alma niyeti üzerine olan etkisinin incelenmesidir. $\mathrm{Bu}$ temel amaç çerçevesinde değişkenler arasındaki ilişkiyi irdelemek için Selçuk Üniversitesi öğrencileri üzerinde ampirik bir çalışma gerçekleştirilmiştir.

$\mathrm{Bu}$ çalışmada sosyal medya reklamlarının etkinliğinin ölçülmesinde Lee ve Hong (2016) tarafından geliştirilen duygusal çekicilik, reklamların yaratıcılığı, reklamların bilgilendiriciliği boyutlarına Shaouf vd. (2016) tarafindan geliştirilen reklamların görsel tasarımı boyutu eklenmiştir. Bu bağlamda sosyal medya reklamlarının etkinliğinin dört boyutlu bir ölçekle ölçülebileceği düşünülmüştür. Tablo 1'deki Keşifsel Faktör Analizi ve Tablo 2'deki Doğrulayıcı Faktör Analizi sonuçlarına göre öne sürülen bu dört boyutlu yeni ölçeğin yapısal geçerliliğinin ve güvenilirliğinin sağlandığı görülmektedir. Bir başka deyişle sosyal medya reklamlarının etkinliği dört boyutlu bu yeni ölçekle ölçülebilecektir.

Çalışmanın temel amacı doğrultusunda kavramsal modelden yararlanılarak 3 temel hipotez geliştirilmiştir. Sosyal medya reklamlarının etkinliği ile empati ifadesine yönelik tutum arasındaki ilişkiyi ölçen $\mathrm{H}_{1}$ hipotezi kabul edilmiştir $(\mathrm{p}<0,001)$. Bu bağlamda sosyal medya reklamlarında reklam etkinliği unsurlarının, tüketicilerin ilgisini çekmede ve reklama karşı bir empati tutumu sergilemesinde önemli bir etkisinin olduğu görülmektedir.

Çalışmada empati ifadesine yönelik tutum ile satın alma niyeti arasındaki ilişkiyi ölçen $\mathrm{H}_{2}$ hipotezi kabul edilirken $(\mathrm{p}<0,05)$, sosyal medya reklamlarının etkinliği ile satın alma niyeti arasındaki ilişkiyi ölçen $\mathrm{H}_{3}$ hipotezi reddedilmiştir ( $>00,05)$. Bu sonuçlar tüketicilerin reklama karşı empati tutumu göstermelerinin satın alma niyetlerinde de güçlü bir etkisinin olduğunu göstermektedir.

$\mathrm{Bu}$ çalışmadan elde edilen sonuçların sadece örneklemin temsil ettiği ana kütle için değerlendirilebilmesi, çalışma için ayrılan bütçe ve çalışmanın yapıldığ 1 dönem önemli bir kısıttır. Bundan sonra yapılması düşünülen olas1 
çalışmaların daha geniş zaman dilimlerinde ve daha geniş bütçelerle farklı örneklemler üzerinde yürütülmesinin literatüre önemli katkılar sağlayacağ 1 düşünülmektedir.

\section{KAYNAKÇA}

Alhabash, S.; McAlister, A.R.; Quilliam, E.T.; Hagerstrom, A.; Rifon, N. and Richards, J. I. (2013). Between likes and shares: effects of emotional appeal and virality on the persuasiveness of anticyberbullying messages on facebook, Cyberpsychology, Behavior and Social Networking, 16, 175182.

Amjad, M.; Javed, R. and Jaskani, N. H. (2015). Examining attitudes and beliefs towards online advertising in Pakistan, International Journal of Scientific ve Engineering Research, 6(1), 463-480.

Anderson, J. C. and Gerbing, D. W. (1984). The effect of sampling error on convergence, improper solutions, and goodness-offit indices for maximum likelihood confirmatory factor analysis, Psychometrika, 49(2), 155-173.

Ayyıldız, H.; Cengiz, E. ve Ustasüleyman, T. (2006). Üretim ve pazarlama bölüm çalışanları arası davranışsal değişkenlerin firma performansı üzerine etkisine ilişkin yapısal bir model önerisi, Muğla Üniversitesi Sosyal Bilimler Enstitüsü Dergisi (ILLKE), 17.

Braun-Latour, K. A. and Zaltman, G. (2006). Memory change: an intimate measure of persuasion, Journal of Advertising Research, 46(1), 57-72.

Can, L. ve Serhateri, A. (2016). Sosyal medya reklamlarının markaya yönelik tutuma etkisi: facebook üzerinde bir uygulama, Balkan ve Yakın Doğu Sosyal Bilimler Dergisi, 2(3), 16-28.

Cho, C.-H. (1999). How advertising works on the www: modified elaboration likelihood model, Journal of Current Issues and Research in Adversiting, 21(1), 33-50.

Cole, D. A. (1987). Utility of confirmatory factoranalysis in test validation research, Journal of Consulting and Clinical Psychology, 55, 1019-1031.

Coşkun, R., Altunışı, R. ve Yıldırım, E. (2017). Sosyal bilimlerde araştırma yöntemleri SPSS uygulamal,, Sakarya Yayınc1lık.

Çakır, Vesile ve Çakır, Vedat (2007), Televizyon reklamlarının algılanan değeri ve reklam tutumu ilişkisi: bir yapısal eşitlik modeli, İstanbul Üniversitesi İletişim Fakültesi Dergisi, 30, 37-59. 
Dao, W. Van-Tien; L., Angelina N. H.; Cheng, J. M.-S. and Chen, D. C. (2014). Social media advertising value: the case of transitional economies in Southeast Asia, International Journal of Advertising, 33(2), 271-294.

Dreze, X. and Zufryden F. (1998). Testing web site design and promotional content, Journal of Consumer Research, 37(2), 77-91.

Eminoğlu, E. ve Nartgün, Z.(2009). Üniversite öğrencilerinin akademik sahtekarlık eğilimlerinin ölçülmesine yönelik bir ölçek geliştirme çalışması, Uluslararası İnsan Bilimleri Dergisi, 6(1), 215-240.

Eröz, S. S. ve Doğdubay, M. (2012). Turistik ürün tercihinde sosyal medyanın rolü ve etik ilişkisi, Dokuz Eylül Üniversitesi İktisadi ve İdari Bilimler Fakültesi Dergisi, 27(1), 133-157.

Escalas, J. E. and Stern, B.B. (2003). Sympathy and empathy: emotional responses to advertising dramas, Journal of Consumer Research, 29, 566578.

Flores, W.; Chen, J.-C. V. and Ross, W. H. (2014). The effect of variations in banner ad, type of product, website context, and language of advertising on internet users' attitudes, Computers in Human Behavior, 31(1), 37-47.

Fornell, Claes and Larcker, David F. (1981). Evaluating structural equation models with unobservable variables and measurement error, Journal of Marketing Research, 18(1), 39-50.

Gaber, H. R. and Wright, L. T. (2014). Fast-food advertising in social media. a case study on facebook in Egypt, Journal of Business and Retail Management Research, 9(1), 52-63.

Gülbahar, Y. ve Büyüköztürk, Ş. (2008). Değerlendirme tercihleri ölçeğinin türkçeye uyarlanması, Hacettepe Üniversitesi Eğitim Fakültesi Dergisi (H. U. Journal of Education), 35, 148-161.

Haberland, G. S. and Dacin, P.A. (1992). The development of a measure to assess viewers' judgments of the creativity of an advertisement: A Preliminary Study, Advances a Consumer Research, 19(1), 817-825.

Haida, A. and Rahim, H. L. (2015). Social media advertising value: a study on consumer's perception, International Academic Research Journal of Business and Technology, 1(1), 1-8.

Hair, J. F; Andreson, R. E.; Tahtam, R.L. and Black W. C. (1998). Multivariate data analysis. Fifth Edition, Prentice-Hall International Inc. 
Hassan, M. Ul; Fatima, S.; Akram, A.; Abbas, J. and Hasnain, A. (2013). Determinants of consumer attitude towards social-networking sites advertisement: testing the mediating role of advertising value, Middle-East Journal of Scientific Research, 16(3), 319-330.

Haşlaman, T. (2005). Programlama dersi ile ilgili özdüzenleyici öğrenme stratejileri ile başarı arasındaki ilişkilerin incelenmesi: bir yapısal eşitlik modeli, [Yüksek Lisans Tezi]. Hacettepe Üniversitesi.

Kirtiş, K. A. and Karahan, F. (2011). To be or not to be in social media arena as the most cost-efficient marketing strategy after the global recession, Procedia Social and Behavioral Sciences, 24, 260-268.

Kontaxis, G.; Polychronakis, M.; Keromytis, A. D. and Markatos, E. P. (2012). Privacy-preserving social plugins, 21st USENIX Conference on Security Symposium, 631-646.

Lee, J. and Hong I.B. (2016). Predicting positive user responses to social media advertising: the roles of emotional appeal, informativeness and creativity, International Journal of Information Management, 36, 360-373.

Ling, K. C.; Piew, T. H. and Chai, L. T. (2010). The determinants of consumers' attitude towards advertising, Canadian Social Science, 6(4), 114-126.

Liu, C.-L. E.; Sinkovics, R. R; Pezderka, N. and Haghirian, P. (2012). Determinants of consumer perceptions toward mobile advertising- a comparison between Japan and Austria, Journal of Interactive Marketing, 26(1), 21-32.

Logan, K.; Bright, L. F. and Gangadharbatla, H. (2012). Facebook versus television: advertising value perceptions among females, Journal of Research in Interactive Marketing, 6(3), 164-179.

Marsh, H. W. and Hocevar, D. (1988). A New, More Powerful Approach to Multitrait-Multimethod Analyses: Application of Second-Order Confirmatory Factor Analysis, Journal of Applied Psychology,73(1), 107117.

Nakip, M. (2013). Pazarlamada araştırma teknikleri SPSS uygulamalı, 3. Baskı, Seçkin Yayıncılık.

Reinartz, W. and Saffert, P. (2013). Creativity in advertising: when it works and when it doesn't, Harvard Business Review, 91(6), 106-111. 
Rosen, L. D. (2012). The Power of 'Like' Psychology Today https://www.psychologytoday.com/intl/blog/rewired-the-psychologytechnology/201207/the-power, Erişim Tarihi: 19.05.2019.

Saputro, Y. and Prihandono, D. (2018). Television advertising effectiveness in mediating advertising creativity and advertising frequency influence toward customer purchase intention, Management Analysis Journal, 7(2), 201-210.

Shaouf, A.; Lü, K. and Li, X. (2016). The effect of web advertising visual design on online purchase intention: an examination across gender, Computers in Human Behavior, 60, 622-634.

Singh, S. N. and Dalal, N. P. (1999). Web home pages as advertisements, Communications of the ACM, 42(8), 91-98.

Smith, R. E.; MacKenzie, S.B.; Yang, X.; Buchholz, L. M. and Darley, W. K. (2007). Modeling the determinants and effects of creativity in advertising. Marketing Science, 26(6), 819-833.

Swani, K.; Milne, G. and Brown, B. P. (2013). Spreading the word through likes on facebook: evaluating the message strategy effectiveness of Fortune 500 companies, Journal of Research in Interactive Marketing, 7(4), 269-294.

Şahin, A.; Cankurt, M.; Günden, C. ve Miran, B. (2008). Çiftçilerin risk davranışları: bir yapısal eşitlik modeli uygulaması, Dokuz Eylül Üniversitesi İktisadi ve İdari Bilimler Fakültesi Dergisi, 23(2), 153-172.

Talih Akkaya, D. (2013). Sosyal medya reklamlarında tüketici algılarının tutum davranış ve satın alma niyeti üzerine etkisi, [Doktora Tezi], Trakya Üniversitesi.

Taylor, D. G.; Lewin, J. E. and Strutton, D. (2011). Friends, fans and followers: do ads work on social networks?, Journal of Advertising Research, 51(1), 258-275.

Tezcan, C. (2008). Yapısal eşitlik modelleri, [Yüksek Lisans Tezi], Hacettepe Üniversitesi.

Tseng, C.-H.; Kuo, H.-C. and Chen, J.-M. (2014). Do types of virtual community matter for the effects of online advertisement and electronic words of mouth?, Marketing Review (Xing Xiao Ping Lun), 11(1), 28- 50. 
Turgut, E.; Akyol, A. ve Giray, S. (2016). Sosyal medya reklamlarında tüketici algılamaları ile satın alma niyeti ve ağızdan ağıza iletişim arasındaki ilişki, Journal of Life Economics, 3(2), 55-74.

Ünal, S.; Erciş, A.l and Keser, E. (2011). Attitudes towards mobile advertisinga research to determine the differences between the attitudes of youth and adults, Procedia Social and Behavioral Sciences, 24, 361-377.

Wang, C.; Zhang, P.; Choi, R. and D’Eredita, M. (2002). Understanding consumers attitude toward advertising, Eighth Americas Conference on Information Systems, 1143- 1148.

Wei, K. K.; Jerome, T. and Shan, L. W. (2010). Online advertising: a study of malaysian consumers, Available at SSRN 1644802, 5(2), 111- 134.

Yazıcıoğlu, Y. ve Erdoğan, S. (2014). SPSS uygulamalı bilimsel araştırma yöntemleri, Detay Yayıncılık.

Yeniçeri, T. ve Erten, E. (2008). Mağaza sadakat programlarının algılanması, güven, ilişkiyi sürdürme isteği ve mağaza sadakati arasındaki ilişkilerin yapısal eşitlik modeli ile incelenmesi, Doğuş Üniversitesi Dergisi, 9(2), 232-247. 